\title{
Keberadaan Hak Kekayaan Intelektual Seni Batik Jambi di Kota Jambi
}

\author{
Syarifa Mahila ${ }^{1}$ \\ Fakultas Hukum Universitas Batanghari Jambi ${ }^{1}$ \\ Email :mahila218@gmail.com.
}

\begin{abstract}
Batik Artwork is a work in the field of Intellectual Property Rights which is more primarily included in the Copyright field. To product a piece of batik cloth, several processes are needed, so that a piece of batik cloth has the possibility of attaching several intellectual property rights other than copyrights.Batik Jambi business is one group of Small and Medium Industries (IKM) that develops in the City of Jambi. Based on data obtained from the Jambi City Office of Trade and Industry, in 2016 there were 98 units of Batik Jambi IKM, in 2017 there were 88 units of Batik Jambi IKM.Each IKM generally has no intellectual property rights. Only limited brands registered with the Trade and Industry Office as brands for registration of business licenses. This is because they still feel that they are not yet in line with the turnover they earn, while registration is certainly a cost.
\end{abstract}

Keywords : Batik Art, Intellectual Property Rights, Legal Protection.

\section{PENDAHULUAN}

Keberadaan HaKI (Hak atas Kekayaan Intelektual) dalam kehidupan manusia dan dalam hubungan pergaulan Internasional antar negara yang saling bergantung tidak dapat dielakkan. Perkembangan ilmu pengetahuan dan teknologi memberi pengaruh terhadap masalah Hak Kekayaan Intelektual. Direktorat Jenderal Hak Kekayaan Intelektual (Ditjen HKI) memberikan perlindungan hukum bagi karya-karya intelektual dan menggalakkan peningkatan karya kreatif dengan menyelenggarakan sistem Hak Kekayaan Intelektual. Sebagai Negara berkembang sesungguhnya keberadaan aturan tentang HKI bisa dikatakan memberikan dampak positif bagi perkembangan perdagangan dan perekonomian. Terutama untuk para pelaku ekonomi kreatif, mereka menjadi pihak yang jelas mendapat tempat didalam perlindungan HKI.

Bangsa Indonesia sebagai negara berkembang tidak mudah dalam menerapkan rezim HKI. Sebab, Indonesia mempunyai kekhasan dalam karakteristik masyarakatnya. Masyarakat di Indonesia merupakan masyarakat komunal yang menempatkan kepentingan bersama lebih tinggi dari kepentingan individu, meskipun itu tidak berarti pula bahwa individu kehilangan hakhaknya. ( Agus Sardjono : 2006: 132 )

Perlindungan HKI yang kuat selain memberikan kepastian hukum, juga memberikan manfaat yang dapat dirasakan dari segi politis, ekonomi, sosial budaya, bahkan segi pertahanan keamanan pun bisa meraih manfaat dari adanya perlindungan HKI ini. Secara garis besarnya kita dapat melihat beberapa keuntungan dan manfaat yang dapat diharapkan dengan adanya perlindungan HKI secara ekonomi, yaitu antara lain:

1) Perlindungan HKI yang kuat dapat memberikan dorongan untuk meningkatkan landasan teknologi nasional guna memungkinkan pengembangan teknologi yang lebih cepat lagi.

2) Pemberian perlindungan hukum terhadap Hak Kekayaan Intelektual pada dasarnya dimaksudkan sebagai upaya untuk mewujudkan iklim yang lebih baik bagi tumbuh dan berkembangnya gairah mencipta atau menemukan sesuatu di bidang ilmu pengetahuan, seni dan sastra.

3) Pemberian perlindungan hukum terhadap HKI bukan saja merupakan pengakuan negara terhadap hasil karya dan karsa manusia, melainkan juga merupakan penciptaan suasana yang sehat untuk menarik penanaman modal asing, serta memperlancar perdagangan internasional. ( Wahyu Agus K: 2010:21 )

Seni Batik merupakan karya yang termasuk dalam bidang Hak Kekayaan Intelektual yang sudah diakui secara Internasional. Indonesia memang kaya dengan tradisi membatiknya, jadi tidak heran jika berbagai cara terus dilakukan untuk melestarikan budaya mengenakan kain bermotif batik, termasuk di Kota Jambi. Batik Jambi memiliki ciri khas tertentu, motif atau desainnya berkaitan dengan kekayaan budaya dan alam dengan mencerminkan sosial/budaya Jambi, gambaran sumber daya Jambi serta memiliki nilai sejarah. 
Beberapa model motif batik Jambi yang diambil dari tema lingkungan sekitar yaitu Kangkung, Keladi, Tali Aek (tumbuhan yang menjalar ke air). Sedangkan unsur tumbuhan yang di jadikan motif batik diambil dari pohon, bunga dan dan buah. Jenis tumbuhan itu antara lain: Bungo Duren, Bungo Pauh, Bungo Kaco Piring, Bungo Tanjung, Bungo Cengkeh. Motif dari unsur fauna yaitu: Kuwaw Berhias, Merak Ngeram dan motif lainnya yang termasuk di dalamnya adalah Kapal Sanggat/Kapal Pecah.

Karya Seni Batik merupakan karya bidang Hak Kekayaan Intelektual yang lebih utamanya termasuk dalam bidang Hak Cipta. Namun untuk menghasilkan selembar kain batik diperlukan beberapa proses, sehingga terhadap selembar kain batik terdapat kemungkinan melekat beberapa Hak Kekayaan Intelektual. Haki untuk produk batik dapat dimiliki secara komunal maupun secara personal tergantung siapa yang menghasilkan karya tersebut.

Mengingat pembahasan tentang batik ini cukup luas, oleh karenanya penulis merumuskan masalah yang akan menjadi perhatian pokok nantinya, yaitu:

1. Hak Kekayaan Intelektual apa saja yang terdapat pada Seni Batik .

2. Bagaimana Keberadaan Hak Kekayaan Intelektual Seni Batik Jambi di Kota Jambi.

\section{Landasan Teoritis}

Untuk melakukan analisis suatu penelitian diperlukan teori. Suatu kerangka teori bertujuan untuk menyajikan cara-cara untuk mengorganisasikan dan menginterpretasikan hasil-hasil penelitian dan menghubungkannya dengan hasil-hasil penelitian terdahulu. (Burhan Ashshofa:1998:23).

Secara umum prinsip utama Haki bahwa siapapun yang menghasilkan suatu karya intelektual, akan mendapatkan pengakuan kepemilikan secara alamiah. Keberadaan Haki sebagai bagian dari privat rights dapat dipedomani teori hukum alam yang dikemukakan oleh John Locke. Menurut John Locke, setiap pribadi mempunyai hak-hak alamiah yang dibawa sejak lahir, yaitu hak hidup, hak atas kebebasan dan hak milik. Menurutnya bahwa property ( kekayaan ) akan melekat pada diri seseorang, apabila ada upaya dari orang tersebut untuk menghasilkan sesuatu dalam dirinya melalui sesuatu (alam) yang sudah disediakan oleh Tuhan. Perolehan alamiah melalui penciptaan telah dianut oleh John Locke dan kaum sosialis yang berkembang dalam sistem Hukum Romawi dengan paham bahwa benda yang diperoleh secara demikian adalah kepunyaan seseorang tersebut atau dikenal dengan asas suum cuique tribuere.

Hegel juga menulis masalah property dalam bukunya Philosophy of Rights, yang menggambarkan perubahan bentuk secara seri dalam masa transisi. Pendekatan Hegel dalam Personality Theory yang menyebutkan bahwa property is the embodiment of personality. Teori ini menekankan pengembangan property sebagai milik personal (Djulaeka:2014:61).

Kedua teori diatas dapat dijadikan sebagai dasar pembahasan tentang pengakuan keberadaan Haki. Kedua filosof tersebut menggambarkan bahwa property (kekayaan) selalu dikaitkan dengan keberadaan sesorang dalam menikmati aktualisasi jerih payahnya dan bersifat personal. Hal ini menjadikan karakteristik Haki sebagai bagian dari hak seseorang secara absolut dan proporsional. Seni batik dapat dikatakan berawal dari pengetahuan yang dimiliki secara komunal. Namun dengan keahlian yang dimiliki oleh masing-masing individu yang mengembangkan seni batik khususnya batik Jambi, menciptakan karya seni batik yang beragam. Dengan demikian karya seni batik khususnya batik Jambi dapat dimiliki secara personal sebagai Haki melalui inovasi yang mereka lakukan.

\section{METODE PENELITIAN.}

Menurut Ronny Hanitijo Soemitro, penelitian merupakan kegiatan yang mengunakan penalaran empirik dan/ atau non empirik dan memenuhi persyaratan metodologi disiplin ilmu yang bersangkutan. ( Roni Haditijo : 2001 ) Metode penelitian adalah cara-cara berfikir dan berbuat, yaitu dipersiapkan dengan baik untuk mengadakan penelitian dan untuk mencapai suatu tujuan penelitian.

\section{Tipe Penelitian}

Tipe penelitian yang digunakan dalam penelitian ini adalah penelitian hukum empiris yaitu menganalisis dan mengkaji bekerjanya hukum di dalam masyarakat. Bekerjanya hukum dalam masyarakat dapat dikaji dari tingkat efektivitas hukum, kepatuhan terhadap hukum, peranan lembaga atau institusi hukum di dalam penegakan hukum, implementasi aturan hukum, pengaruh aturan hukum, pengaruh aturan hukum terhadap masalah sosial tertentu atau sebaliknya, pengaruh masalah sosial terhadap aturan hukum ( Salim.HS: 2014:20). Pada penelitian ini peneliti akan mengkaji tentang efektivitas 
hukum dalam hal ini tentang efektivitas aturan hukum yang mengatur tentang Hak Kekayaan Intelektual khususnya terhadap seni batik Jambi.

\section{Metode Pendekatan}

Dalam pendekatan yang digunakan dalam penelitian hukum empiris yang menjadi fokus kajiannya pada bekerjanya hukum dalam masyarakat. Penelitian ini menggunakan pendekatan sosiologi hukum. Pendekatan sosiologi hukum merupakan pendekatan yang menganalisis tentang bagaimana reaksi dan interaksi yang terjadi ketika sistem norma itu bekerja di dalam masyarakat. ( Salim.HS : 2014:23). Dalam hal ini adalah sistem hukum yang berkaitan dengan perlindungan Hak Kekayaan Intelektual.

\section{Tehnik Penentuan Sampel}

Penetapan sample dilakukan dengan tehnik Non Probabilitas atau Non Random Sampling dalam hal ini dipakai Purposive Sampling dengan cara mengambil subyek didasarkan pada tujuan tertentu.

Responden dalam penelitian ini adalah :

a. Kepala Dinas Perdagangan dan Perindustrian Kota Jambi.

b. Kasubbid Ahu dan KI Kantor Kementrian Hukum \& HAM Wilayah Jambi.

c. Pengrajin Batik Jambi 2 orang.

\section{Jenis dan Sumber Data}

Jenis dan sumber data yang dipergunakan dalam penelitian ini adalah terdiri dari data primer dan data skunder:

a. Data Primer dikumpulkan dengan cara wawancara bebas terpimpin yaitu dengan mempersiapkan terlebih dahulu pertanyaanpertanyaan sebagai pedoman dengan tetap dimungkinkan adanya variasi pertanyaan yang disesuaikan dengan situasi pada saat wawancara.

b. Data Sekunder, adalah perolehan data dengan studi dokumen yang meliputi :

1. Bahan hukum Primer, yaitu bahan-bahan hukum yang bersifat mengikat yang terdiri dari :

a) Kitab Undang-Undang Hukum Perdata,

b) Undang - undang Nomor 28 Tahun 2014 tentang Hak Cipta.

c) Undang - undang Nomor 13 Tahun 2016 tentang Paten. d) Undang - undang Nomor 20 Tahun 2016 tentang Merek dan Indikasi Geografis

e) Undang - undang Nomor 30 Tahun 2000 tentang Rahasia Dagang.

2. Bahan hukum Skunder, yang memberikan penjelasan mengenai bahan hukum Primer, yaitu :

a) Sebagai landasan teoritis berupa pendapat-pendapat atau tulisan- tulisan para ahli atau pihak-pihak lain yang berwenang untuk memperoleh informasi baik bentuk ketentuan formal melalui naskah resmi/ makalahmakalah yang ada.

b) Dokumen yang berkaitan dengan Perlindungan hukum Hak Kekayaan Intelektual.

c) Buku-buku tentang Hukum Perdata, Hak Kekayaan Intelektual.

\section{Analisa Data}

Mengingat penelitian ini merupakan penelitian yang bersifat deskriptif, maka penelitian ini menggunakan metode analisis kualitatif yaitu apa yang dinyatakan oleh responden secara tertulis atau lisan dan juga perilakunya yang nyata, diteliti dan dipelajari sebagai suatu yang utuh. Dari hasil tersebut kemudian ditarik suatu kesimpulan yang merupakan jawaban atas permasalahan yang diangkat dalam penelitian ini.

\section{Pengertian Hak Kekayaan Intelektual}

Istilah Haki (HKI) merupakan terjemahan dari Intellectual Property Right yang dideskripsikan sebagai hak atas kekayaan yang timbul karenakemampuan intelektual manusia. Istilah Haki bukanlah satu-satunya terjemahan dari kata Intellectual Property Right. "Secara substansi, pengertian Haki dapat dideskripsikan sebagai hak atas kekayaan intelektual yang timbul dan lahir karena kemampuan intelektual manusia". ( Afriliyana Purba: 2005:13)

Pada intinya Pengertian Hak Atas Kekayaan Intelektual (HaKI) atau Haki (HKI) dan Intellectual Property Rights (IPR) adalah hak untuk menikmati secara ekonomis hasil dari suatu kreativitas intelektual. Berdasarkan pengertian ini maka perlu adanya penghargaan atas hasil karya yang telah dihasilkan yaitu perlindungan hukum bagi kekayaan intelektual tersebut. Tujuannya adalah 
untuk mendorong dan menumbuh kembangkan semangat terus berkarya dan mencipta.

Aspek atau segi ekonomi dapat menampilkan kajian bahwa Haki adalah objek kekayaan yang dapat ditransaksikan dalam proses tukar menukar kebutuhan ekonomis manusia. Ditinjau dari aspek politik Haki menjadi instrumen negara-negara maju untuk memengaruhi negara-negara berkembang setelah isu tentang Haki dimasukan menjadi isu pokok dalam World Trade Organization (WTO) yang melahirkan The Agreement on Trade Related Aspects of Intellektual Property Rights ( TRIPs Agreement) dan instrumen hukum ikutannya. (OK.Saidin:2015:1). Sistem HaKI merupakan hak privat (private rights). Seseorang bebas untuk mengajukan permohonan atau mendaftarkan karya intelektualnya atau tidak.

Klasifikasi Haki berdasarkan persetujuan TRIPs tercantum pada Part II tentang Standart Conserning Aviability, Scope and Use of Intellectual Property Rights terdiri dari:

(1) Copyrights and Related Rights.

(2) Trademark.

(3) Geographical Indication.

(4) Industrial Design

(5) Patent

(6) Layout designs of integrated Circuits.

(7) Protection of Undiclosed Information.

(8) Control of Anti Competitive Practicesin Contractual Licences.

(Kholis

Roisah:2015:11)

Klasifikasi Haki berdasarkan hukum nasional Indonesia, tidak sepenuhnya mengikuti instrumen Internasional, tetapi aturan hukumnya tetap menyesuaikan dengan persetujuan TRPs. Klasifikasi Haki menurut hukum Indonesia yaitu

(1) Hak Cipta dan Hak Terkait.

(2) Paten

(3) Merek

(4) Desain Industri

(5) Desain Tata Letak Sirkuit Terpadu.

(6) Rahasia Dagang

(7) Perlindungan Varitas Tanaman.

\section{Sejarah Singkat Perkembangan Batik Jambi}

Keberadaan batik Jambi sudah ada sejak tahun 1875. Sejak jaman Kerajaan Melayu batik Jambi sudah dikerjakan secara turun temurun oleh para kerabat dan keluarga istana Kerajaan Melayu Jambi namun setelah runtuhnya kerajaan serta dengan adanya penjajahan yang dilakukan oleh bangsa lain seperti Jepang dan Belanda kegiatan pembatikan mulai berkurang dan sempat berhenti, hanya beberapa orang saja yang masih membatik.

Pertengahan tahun 70-an ditemukan beberapa lembar kain batik kuno. Hal ini mendorong Kanwil Departemen Perindustrian/Dinas Perindustrian Tingkat I Jambi untuk menggali dan menumbuhkan kembali kegiatan pembatikan kain batik Jambi diawali dengan melatih ibu Rts. Hadijah dan mendatangkan ahli batik dari Balai Batik. (Asianto dalam Suhikmah:1998:40).

Sejak itu batik Jambi mulai kembali dikenal namun masih pada kalangan terbatas karena produksinya sangat minim. Sejalan dengan itu industri batik di Jambi mulai berkembang, tapi masih dalam skala kecil atau yang biasa dikenal dengan istilah home industri yang termasuk katergori industri kecil.

\section{HASIL DAN PEMBAHASAN}

\section{Hak Kekayaan Intelektual Pada Seni Batik}

Pembuataan batik dibutuhkan ketekunan, keuletan, kecermatan, dan keahlian untuk menghasilkan sebuah motif batik yang beraneka ragam yang dipengaruhi berbagai faktor. Ekspresi dari pembuatan batik inilah yang menyebabkan batik menjadi suatu seni.

Pembuatan batik melalui beberapa tahap, dengan demikian pada produk batik dapat memiliki beberapa hak kekayaan Intelektual tergantung si penemunya dan memang yang paling utama adalah hak cipta. Hakikatnya hak cipta batik ini sebenarnya memberikan perlindungan bagi si pencipta untuk menikmati secara materil jerih payahnya dari karya cipta tersebut. Batik yang termasuk sebagai pengetahuan tradisional mendapatkan perlindungan agar karya cipta seni batik milik Indonesia yang menjadi warisan budaya bangsa ini tidak dimiliki/ditiru oleh negara lain. Seandainya negara lain ada yang ingin meniru maka harus membayar royalti kepada pemerintah Negara Indonesia yang nantinya dapat menjadi salah satu sumber devisa negara.

Bentuk perlindungan hukum sebuah karya cipta seni batik yang diperoleh melalui pendaftaran hak cipta, antara lain sebagai berikut:

a. Pencipta maupun pemegang hak cipta seni batik akan mendapatkan kepastian hukum mengenai hak cipta seni batik dalam arti mendapatkan pengakuan hak atau ciptaannya.

b. Memberikan kedudukan lebih kuat apabila 
terjadi sengketa daripada pencipta atau pemegang hak yang tidak mendaftarakan hak ciptanya guna mempermudah proses pembuktian apabila ada suatu permasalahan atau sengketa. Hasil dari pendaftaran tersebut berupa sertifikat dari Ditjen HKI. Sertifikat inilah yang nantinya dapat menyakinkan dan membantah pihak lawan.

Karya seni batik termasuk sebagai karya cipta yang dilindungi menurut Pasal 40 ayat (1) huruf j Undang-Undang Nomor 28 Tahun 2014 tentang Hak Cipta ("UU Hak Cipta"). Yang dimaksud dengan "karya seni batik" adalah motif batik kontemporer yang bersifat inovatif, masa kini, dan bukan tradisional. Karya tersebut dilindungi karena mempunyai nilai seni, baik dalam kaitannya dengan gambar, corak, maupun komposisi warna.

Pasal 1 Undang-Undang Nomor 28 Tahun 2014 tentang Hak Cipta:

1. Hak Cipta adalah hak eksklusif pencipta yang timbul secara otomatis berdasarkan prinsip deklaratif setelah suatu ciptaan diwujudkan dalam bentuk nyata tanpa mengurangi pembatasan sesuai dengan ketentuan peraturan perundang-undangan.

2. Pencipta adalah seorang atau beberapa orang yang secara sendiri-sendiri atau bersamasama menghasilkan suatu ciptaan yang bersifat khas dan pribadi.

3. Ciptaan adalah setiap hasil karya cipta di bidang ilmu pengetahuan, seni, dan sastra yang dihasilkan atas inspirasi, kemampuan, pikiran, imajinasi, kecekatan, keterampilan, atau keahlian yang diekspresikan dalam bentuk nyata.

Perlindungan hak cipta dibagi menjadi dua, yaitu perlindungan terhadap hak moral dan perlindungan terhadap hak ekonomi.

Perlindungan terhadap hak moral pencipta untuk:

(1) tetap mencantumkan atau tidak mencatumkan namanya pada salinan sehubungan dengan pemakaian ciptaannya untuk umum;

(2) menggunakan nama aliasnya atau samarannya;

(3) mempertahankan haknya dalam hal terjadi distorsi ciptaan, mutilasi ciptaan, modifikasi ciptaan, atau hal yang bersifat merugikan kehormatan diri atau reputasinya.

Masa perlindungan hak moral diberikan tanpa batas waktu sesuai dengan Pasal 57 ayat (1) UU 28 Tahun 2014. Untuk hak ekonomi, perlindungannya diberikan selama hidup pencipta dan terus berlangsung selama 70 tahun setelah pencipta meninggal dunia, terhitung mulai tanggal 1 Januari tahun berikutnya (Pasal 58 ayat (1) UU 28 Tahun 2014). Apabila hak cipta tersebut dimiliki oleh suatu badan hukum, maka masa perlindungannya berlaku selama 50 tahun sejak pertama kali dilakukan pengumuman.

Jenis ciptaan yang perlindungannya diberikan selama hidup pencipta ditambah 70 tahun setelah pencipta meninggal dunia seperti yang diatur dalam Pasal 58 tersebut hanya berlaku untuk ciptaan:

a. buku, pamflet, dan semua hasil karya tulis lainnya;

b. ceramah, kuliah, pidato dan Ciptaan sejenis lain;

c. alat peraga yang dibuat untuk kepentingan pendidikan dan ilmu pengetahuan;

d. lagu atau musik dengan atau tanpa teks;

e. drama, drama musikal, tari, koreografi, pewayangan, dan pantomim;

f. karya seni rupa dalam segala bentuk seperti lukisan, gambar, ukiran, kaligrafi, seni pahat, patung, atau kolase;

g. karya arsitektur;

h. peta; dan

i. karya seni batik atau seni motif lain.

Sementara itu, untuk jenis ciptaan yang berupa:

a. karya fotografi;

b. potret;

c. karya sinematografi;

d. permainan video;

e. program komputer;

f. perwajahan karya tulis;

g. terjemahan, tafsiran, saduran, bunga rampai, basis data, adaptasi, aransemen, modifikasi, dan karya lain dari hasil transformasi;

h. terjemahan, adaptasi, aransemen, transformasi atau modifikasi ekspresi budaya tradisional;

i. kompilasi ciptaan atau data, baik dalam format yang dapat dibaca dengan program komputer atau media lainnya; dan

j. kompilasi ekspresi budaya tradisional selama kompilasi tersebut merupakan karya yang asli;

Sesuai dengan Pasal 59 ayat (1), perlindungannya diberikan selama 50 tahun 
sejak pertama kali dilakukan pengumuman. Sementara untuk ciptaan yang berupa karya seni terapan, menurut Pasal 59 ayat (2) perlindungannya diberikan selama 25 tahun sejak pertama kali dilakukan pengumuman.

Selain hak cipta, pada produk batik dapat juga mengajukan pendaftaran hak merek. Dalam perlindungan Hukum Merek, ada perlindungan Indikasi Geografis, yaitu suatu tanda yang menunjukkan daerah asal suatu barang dan/atau produk yang karena faktor lingkungan geografis termasuk faktor alam, faktor manusia atau kombinasi dari kedua faktor tersebut memberikan reputasi, kualitas, dan karakteristik tertentu pada barang dan/atau produk yang dihasilkan.

Hal ini diatur dalam Pasal 1 angka 7 Undang-Undang Nomor 20 Tahun 2016 tentang Merek dan Indikasi Geografis ("UU Merek dan IG"), hak atas Indikasi Geografis adalah hak eksklusif yang diberikan oleh negara kepada pemegang hak Indikasi Geografis yang terdaftar, selama reputasi, kualitas, dan karakteristik yang menjadi dasar diberikannya pelindungan atas Indikasi Geografis tersebut masih ada.

Ketentuan mengenai Indikasi Geografis diatur dalam Pasal 53 UU Merek dan Indikasi Geografis sebagai berikut:

(1) Indikasi Geografis dilindungi setelah Indikasi Geografis didaftar oleh Menteri.

(2) Untuk memperoleh pelindungan sebagaimana dimaksud pada ayat (1), Pemohon Indikasi Geografis harus mengajukan Permohonan kepada Menteri.

(3) Pemohon sebagaimana dimaksud pada ayat (2) merupakan:

a. lembaga yang mewakili masyarakat di kawasan geografis tertentu yang mengusahakan suatu barang dan/atau produk berupa:

1. sumber daya alam;

2. barang kerajinan tangan; atau

3. hasil industri.

b. pemerintah daerah provinsi atau kabupaten/kota.

Produk Batik dihasilkan tentunya melalui beberapa proses yang dilakukan oleh pengrajin yang membentuk industri, baik industri kecil, menengah maupun sudah berkembang menjadi industri besar. Sehingga selembar batik sudah pasti merupakan hasil industri. Oleh karena batik merupakan hasil industri maka dapat diberi peluang untuk didaftarkan oleh pengrajin atau pengusahanya sebagai Haki dalam bentuk hak
Indikasi Geografis sebagaimana diatur pada Pasal 53 UU Merek dan Indikasi Geografis. Kenapa produk batik dapat didaftarkan sebagai Haki Indikasi Geografis, hal ini dikarenakan produk batik merupakan karya seni yang mempunyai ciri khas tersendiri pada masingmasing daerah. Untuk membedakan antara produk batik yang dihasilkan oleh masingmasing pengrajin yang tentunya juga mempunyai perbedaan, maka masing-masing pengrajin atau pengusaha batik dapat mendaftarkan merek produknya masing-masing.

Pada proses pembuatan dan pewarnaan produk batik secara umum sama, namun masingmasing pengrajin/pengusaha batik tentunya mempunyai cara dan kiat-kiat tersendiri untuk menghasilkan produk batik yang berkualitas. Kiat-kiat tersebut merupakan rahasia dagang yang sangat berharga bagi pemiliknya. Jika rahasia dagang tersebut dimanfaatkan oleh pihak lain tanpa izin dan dengan cara curang, maka tidak menutup kemungkinan dapat mempengaruhi omset pemiliknya. Untuk itu setiap pengrajin/pengusaha batik wajib menjaga kerahasiaan rahasia dagangnya. Menjaga kerahasiaan rahasia dagang merupakan syarat wajib untuk mendapatkan perlindungan rahasia dagangnya. Jika ada pihak lain yang meniru atau membocorkannya tanpa izin pemiliknya, dapat digugat untuk membayar ganti rugi. Diantara bentuk rahasia dagang yaitu komposisi zat pewarna sehingga menghasilkan warna yang khas dan kualitas tersendiri yang merupakan ciri dan nilai jual dari masing-masing pengrajin/pengusaha batik.

Rahasia Dagang, sebagaimana ternyata dalam Pasal 1 poin 1 UU Nomor 30 tahun 2000 tentang Rahasia Dagang ("UU Rahasia Dagang"), didefinisikan sebagai berikut :

"Rahasia Dagang adalah informasi yang tidak diketahui oleh umum di bidang teknologi dan/atau bisnis, mempunyai nilai ekonomi karena berguna dalam kegiatan usaha dan dijaga kerahasiannya".

Menurut Pasal 2 UU Rahasia Dagang, ruang lingkup dari rahasia dagang tersebut meliputi metode produksi, metode pengolahan, metode penjualan atau informasi lain di bidang teknologi dan/atau bisnis yang memiliki nilai ekonomi yang tidak diketahui masyarakat umum. Kesimpulannya, Rahasia Dagang merupakan informasi yang tidak diungkapkan (undisclosed informations), oleh karena itu harus dijaga kerahasiaannya dengan sebagaimana mestinya. 
Rahasia dagang tersebut, menurut UU Rahasia Dagang tidak perlu didaftarkan atau dicatatkan. Kepemilikan rahasia dagang otomatis dimiliki oleh pemegang haknya, ketika unsurunsur obyek atas hak rahasia dagang terpenuhi. Pencatatan rahasia dagang wajib dilakukan hanya saat terjadi saat pengalihan hak, yaitu atas terjadinya pewarisan, hibah, wasiat perjanjian tertulis atau sebab-sebab lain yang dibenarkan oleh peraturan undang-undang. Salah satu bentuk pengalihan hak adalah dengan pemberian lisensi. Lisensi, dalam Pasal 1 angka 5 UU Rahasia Dagang, didefinisikan sebagai izin yang diberikan oleh pemegang hak rahasia dagang kepada pihak lain melalui perjanjian pemberian hak (bukan pengalihan hak). Dengan diberikan lisensi, maka penerima hak akan menikmati manfaat ekonomi dari Rahasia Dagang yang diberikan perlindungan, melalui jangka waktu dan syarat tertentu.

Pada proses pembuatan batik dapat dilakukan pengembangan metode proses pembuatannya yang menurut ketentuan tentang Haki sebagai hak paten. Hak Paten diatur dalam UU No. 13 Tahun 2016 tentang Paten ("UU Paten") dimana pengertian Paten dalam UU Paten adalah sebagai berikut:

Paten adalah hak eksklusif yang diberikan oleh negara kepada inventor atas hasil invensinya di bidang teknologi untuk jangka waktu tertentu melaksanakan sendiri invensi tersebut atau memberikan persetujuan kepada pihak lain untuk melaksanakannya. Paten itu hak kekayaan intelektual yang diperuntukan untuk penemuan di bidang teknologi bukan logo (merk).

Perlindungan Hak Paten adalah meliputi:

(1) Paten, yaitu diberikan untuk Invensi yang baru, mengandung langkah inventif, dan dapat diterapkan dalam industri. Jangka waktu perlindungan Paten yaitu 20 (dua puluh) tahun terhitung sejak tanggal penerimaan dan tidak dapat diperpanjang.

(2) Paten Sederhana, yaitu diberikan untuk setiap Invensi baru berupa pengembangan dari produk atau proses yang telah ada dan dapat diterapkan dalam industri. Jangka waktu perlindungan Paten Sederhana yaitu 10 (sepuluh) tahun terhitung sejak tanggal penerimaan dan tidak dapat diperpanjang.

Invensi dalam Paten tidak meliputi:

(1) kreasi estetika;

(2) skema;
(3) aturan dan metode untuk melakukan kegiatan yang melibatkan kegiatan mental; permainan; dan bisnis.

(4) aturan dan metode yang hanya berisi program komputer;

(5) presentasi mengenai suatu informasi; dan

(6) temuan (discovery) berupa (i) penggunaan baru untuk produk yang sudah ada dan/ atau dikenal;dan (ii) bentuk baru dari senyawa yang sudah ada yang tidak menghasilkan peningkatan khasiat bermakna dan terdapat perbedaan struktur kimia terkait yang sudah diketahui dari senyawa.

Masyarakat masih banyak yang keliru beranggapan bahwa perbuatan mendaftarkan merek maupun hak cipta dengan menggunakan istilah mematenkan. Istilah mendaftarkan paten merek atau mematenkan merk atau daftar hak paten merek adalah keliru dimana paten dan merek merupakan hak kekayaan intelektual yang berbeda. Pengertian dan perlindungan Paten sebagaimana telah diuraikan diatas.

Pengertian merek sebagaimana diatur pada Pasal 1 angka (1) UU No 20 Tahun 2016 tentang Merek dan Indikasi Geografis ("UU Merek \& IG") bahwa

Merek adalah tanda yang dapat ditampilkan secara grafis berupa gambar, logo, nama, kata, huruf, angka, susunan warna, dalam bentuk 2 (dua) dimensi dan/atau 3 (tiga) dimensi, suara, hologram, atau kombinasi dari 2 (dua) atau lebih unsur tersebut untuk membedakan barang dan/atau jasa yang diproduksi oleh orang atau badan hukum dalam kegiatan perdagangan barang dan/atau jasa.

Hak atas Merek diperoleh setelah Merek tersebut terdaftar. Merek terdaftar mendapat pelindungan hukum untuk jangka waktu 10 (sepuluh) tahun sejak Tanggal Penerimaan dan dapat diperpanjang untuk jangka waktu yang sama. Berdasarkan uraian diatas, dapat disimpulkan bahwa pada produk batik terdapat peluang untuk mendaftarkan beberapa jenis Hak Kekayaan Intelektual yang berfungsi untuk melindungi karya seseorang dalam bidang seni batik yang tidak terbatas pada perlindungan hak cipta saja.

\section{Keberadaan Hak Kekayaan Intelektual Pada Seni Jambi di Kota Jambi. Batik}

Usaha Batik Jambi merupakan salah satu kelompok Industri Kecil dan Menengah (IKM) yang berkembang di Kota Jambi dan bahkan menjadi salah satu produk unggulan daerah. 
Pada tahun 2016 tercatat 98 unit IKM Batik Jambi yang tersebar di beberapa kecamatan yang ada di Kota Jambi yaitu Kecamatan Danau Teluk dan Pelayangan ( Kawasan Sebrang Kota Jambi /sekoja ), Kecamatan Danau Sipin, Kecamatan Telanai Pura, Kecamatan Kota Baru, , Kecamatan Jambi Selatan, Kecamatan Pasar, Kecamatan Jelutung \& Kecamatan Jambi Timur. (Data Disperindag Kota Jambi Desember 2016). Pada tahun 2017 tercatat 88 unit IKM Batik Jambi yang tersebar pada beberapa kecamatan yang sama pada data tahun 2016. (Data Disperindag Kota Jambi 2017).

Meningkatkan daya saing IKM Batik Jambi dapat dilakukan melalui inovasi dalam motif, warna dan produk turunannya guna menghadapi serbuan produk batik dan tekstil lainnya. Pemberian nama pada motif Batik Jambi, diberikan pada setiap satu bentuk motif seperti Batang Hari, Bungo Pauh, Duren Pecah, Kapal Sanggat, Merak Ngeram, Tampok Manggis, Candi Muara Jambi, Kaca Piring, Puncung Rebung, dan Angso Duo Bersayap. Artinya, penamaan bukan diberikan pada suatu rangkaian bentuk dari berbagai unsur atau elemen yang telah didesain sedemikian rupa dan telah menjadi satu kesatuan yang utuh. Meskipun demikian dalam penerapannya tidak monoton pada satu motif saja dan sehelai kain biasanya terdiri dari motif pokok dengan didampingi motif isian lainnya seperti motif tabor titik, tabor bengkok, dan belah ketupat.

Pengrajin Batik Jambi mayoritas terpusat di kawasan Seberang Kota Jambi yang menghasilkan berbagai macam corak dan motif. Seperti motif angsoduo, keris siginjai, sungai batanghari, durian pecah, kapal dan motif-motif lainnya. Sekoja merupakan sentra batik terbesar di Jambi. Daerah Jambi memiliki pengrajin yang aktif berproduksi di setiap kelurahannya. (jambi.antaranews.com:2017). Dekranasda Provinsi Jambi mengutamakan pengembangan batik dengan tetap mempertahankan kearifan lokal.

Pada produk batik terdapat kemungkinan diberikan beberapa macam Hak Kekayaan Intelektual (Haki). Demikian juga halnya pada produk batik Jambi dapat didaftarkan berbagai Haki untuk melindungi karyanya dari kecurangan pihak lain. Namun sangat disayangkan bahwa industri batik Jambi di kota Jambi sebagian besar hanya mendaftar dalam bentuk izin usaha saja sebagaimana yang terdaftar pada Dinas Perdagangan \&
Perindustrian Kota Jambi. Sedangkan pendaftaran hak cipta produk batik Jambi masih sangat minim, apalagi pendaftaran mereknya, sebagaimana yang dikemukakan oleh Kasubbid AHU dan Karya Intelektual Kementrian Hukum \& HAM RI Kantor Wilayah Jambi, Bpk.Zulhendri Faisal, SH.MH. : Masyarakat masih sedikit yang mendaftarkan hak cipta produk batik yang mereka buat. Yang mengajukan hak cipta melalui kantor KumHam Wilayah Jambi kebanyakan merupakan hak cipta dari bidang lainnya. Kantor KumHam hanya mencatat register permohonan, selanjutnya apakah permohonan tersebut diterima atau tidak, informasinya langsung kepada yang bersangkutan, sehingga kami tidak punya data lengkap pemegang sertifikat HAKI yang diajukan oleh masyarakat Jambi.

Pendaftaran dapat dilakukan secara on line dan cukup mencatatkan regitrasinya saja pada Kantor Kementrian Hukum \& HAM daerah. Kementrian Hukum \& HAM Kantor Wilayah Jambi tidak mempunyai data lengkap tentang Haki yang sudah diterima dan yang sudah mempunyai sertifikat. Untuk itu diperlukan penelitian lebih lanjut tentang kepemilikan haki khususnya pada produk batik Jambi di Kota Jambi.

Dengan semakin pesatnya pertumbuhan batik dan makin terbukanya pasar global, untuk melindungi desain motif batik Jambi, pemerintah daerah Jambi bekerjasama dengan Dekranasda Jambi telah mendaftarkan ciptaan seni batik Jambi pada Dirjen HaKI, untuk mendapatkan perlindungan hak cipta dengan tujuan motif Jambi dapat terjaga keaslian dan kelestariannya. Beberapa motif yang telah mendapatkan Hak Cipta (HaKI) dan akan terus diperjuangkan, sebagaimana daftar berikut :

\begin{tabular}{lll}
\hline No. & Judul Motif & Asal \\
\hline 1. & Kuau Berhias & Provinsi Jambi \\
2. & Bungo Pauh & Provinsi Jambi \\
3. & Bungo Melati & Provinsi Jambi \\
4. & Merak Ngeram & Provinsi Jambi \\
5. & Kapal Sanggat & Provinsi Jambi \\
6. & Duren Pecah & Provinsi Jambi \\
7. & Kepak Lepas & Provinsi Jambi \\
8. & Tagapo & Provinsi Jambi \\
9. & Sisik Ikan & Provinsi Jambi \\
10. & Bungo Antelas & Provinsi Jambi \\
11. & Batanghari & Provinsi Jambi \\
12. & Bungo Bangkai & Kabupaten Bungo \\
13. & Bungo Sawit & Kabupaten Batanghari \\
14. & Punai Merindu & Kabupaten Batanghari \\
15. & Perahu Pencolong & Kabupaten Batanghari
\end{tabular}


16. Bungo Nago Sari

17. Daun Karet

18. Pohon Rotan

(Jambikota.go.id: 2018).

Setiap kabupaten/kota se-Propinsi Jambi, telah pula membuat ciri khas desain batik dari daerah masing - masing, seperti Kota Jambi mempunyai motif khas yaitu merak ngeram, batanghari, kapal sanggat, duren pecah, dll. Pemegang sertifikat hak ciptanya adalah provinsi Jambi. Hal ini dikarenakan Kota Jambi merupakan ibu kota provinsi Jambi, maka sulit memisahkan secara khusus kepemilikan Haki untuk produk batik ini.

Dari data yang diperoleh tersebut diatas terlihat bahwa sertifikat Haki produk batik Jambi khususnya kota Jambi baru terbatas pada hak cipta. Sementara untuk hak merek masih terbatas pada pendaftaran merek sebagai nama usaha industri batik atau nama untuk izin usaha batik, itupun pada Dinas Perdagangan dan Perindustrian sebagaimana hasil wawancara peneliti dengan beberapa orang pemilik sanggar batik yang ada di seberang kota Jambi ( sekoja). Salah seorang Pengrajin \& pemilik sanggar batik di kota Jambi mengatakan bahwa mereka para pengrajin sudah sering mengikuti seminar maupun pelatihan tentang batik termasuk pelatihan tentang pendaftaran hak kekayaan intelektual yang diadakan oleh Kementrian Hukum \& HAM kantor wilayah Jambi maupun oleh Dinas Perdagangan \& Perindustrian Kota Jambi. Hal senada juga disampaikan oleh pengrajin batik Jambi lainnya di Sekoja. Namun para pengrajin masih belum melakukan pendaftaran secara individu, baik hak cipta maupun merek, menurut mereka karena masih mempertimbangkan biaya pendaftaran, sementara omset mereka belum memadai.

Berdasarkan beberapa informasi yang didapat sebagaimana diuraikan diatas dapat disimpulkan bahwa keberadaan Hak Kekayaan Intelektual batik Jambi khususnya Kota Jambi baru terbatas pada kepemilikan Hak Cipta yang dimiliki oleh pemerintah daerah. Sedangkan pendaftaran hak cipta bagi masing-masing individu masih kurang diminati oleh masyarakat, padahal mereka mempunyai karya dalam bentuk kreasi baru pengembangan dari motif yang sudah ada. Demikian juga dengan teknis pewarnaan dan teknis proses pembuatan batik yang dikembangkan oleh masing-masing pengrajin dapat dijadikan sebagai Haki milik individu sebagai hak Rahasia Dagang atau sebagai hak
Paten maupun hak Merek. Dengan demikian Haki untuk batik Jambi tidak hanya dimiliki oleh pemerintah daerah, tetapi dapat juga dimiliki secara individu oleh pengrajin. Hal ini tentu saja merupakan peluang untuk meningkatkan pendapatan mereka tidak hanya dari hasil menjual produknya saja, tetapi juga dapat memperoleh pendapatan dari perjanjian lisensi dengan pihak lain dari Haki yang mereka miliki.

\section{SIMPULAN}

Dari uraian pada bab pembahasan dapat disimpulkan beberapa hal sebagai berikut:

1. Pembuatan produk batik melalui beberapa tahapan dari mulai pembuatan desain motif, melukis dengan lilin cair pada kain, pewarnaan, nglorot selanjutnya proses pencucian dan pengeringan, yang masingmasing memerlukan keahlian dan kreatifitas tersendiri. Dengan beberapa tahapan tersebut maka pada produk batik terdapat beberapa hak kekayaan intelektual yang perlu mendapatkan perlindungan, seperti hak cipta, rahasia dagang, hak paten, indikasi geografis dan merek .

2. Batik Jambi merupakan salah satu produk unggulan UMKM provinsi Jambi, demikian juga Kota Jambi. Usaha Batik Jambi merupakan salah satu kelompok Industri Kecil dan Menengah ( IKM ) yang berkembang di Kota Jambi. Berdasarkan data yang diperoleh pada Dinas Perdagangan dan Perindustrian Kota Jambi, bahwa pada tahun 2016 tercatat 98 Unit IKM Batik Jambi, pada tahun 2017 terdapat 88 unit IKM Batik Jambi. Masing-masing IKM pada umumnya belum mempunyak hak kekayaan intelektual. Hanya terbatas merek yang didaftar pada Dinas Perdagangan dan Perindustrian sebagai merek untuk pendaftaran izin usaha. Hal ini disebabkan karena mereka masih merasa belum sesuai dengan omset yang mereka peroleh, sementara untuk pendaftaran tentu dibutuhkan biaya.

\section{DAFTAR PUSTAKA}

\section{Buku}

Abdulkadir Muhammad, "Hukum Perdata Indonesia" , PT.Citra Aditya Bakti, Bandung, 2000.

Afrillyanna Purba, TRIPs-WTO \& Hukum HKI Indonesia Kajian Perlindungan Hak Cipta Seni Batik Tradisional Indonesia. Jakarta: Rineka Cipta, 2005.

Agus Sardjono, Hak Kekayaan Intelektual dan 
Pengetahuan Tradisional,Bandung: PT.Alumni, 2006.

Burhan Ashshofa, Metode Penelitian Hukum, Rineka Cipta Jakarta, 1998.

Djulaeka, Konsep Perlindungan Haki Perspektif Kajian Filosofis HaKI KolektifKomunal,Setara Press, Jawa Timur, 2014.

Kholis Roisah, Konsep Hukum Hak Kekayaan Intelektual, Setara Pres : Malang, 2015.

M. Solly Lubis, Filsafat Ilmu dan Penelitian, Mandar Maju Bandung, 1994

OK.Saidin, Aspek Hukum Hak Kekayaan Intelektual ( Intelectual Property Rights), PT. RajaGrafindo Persada : Jakarta, 2015.

Sudjana Sudaryat, dan Rika Ratna Permata, Hak Kekayaan Intelektual, Memahami prinspdasar, cakupan dan UndangUndang yang berlaku, Bandung: Oase Media, 2010.

Salim HS \& Erlies Septiana Nurbani, Penerapan Teori Hukum Pada Penelitian Tesis Dan Desertasi, Jakarta: Rajagrafindo Persada, 2014.

Jurnal Ilmiah

Suhikmah, Upaya Pemerintah Daerah Jambi Dalam Rangka Perlindungan Hukum Terhadap Ciptaan Motif Batik Yang Belum Terdaftar, Tesis, 2008.

Wahyu Agus Kurniawati As, Studi Perlindungan Hukum Hak Cipta Seni Batik di Kota Surakarta, Skripsi tahun 2010.

Moch Najib Imanullah dkk. "Problematika Hak Kekayaan Intelektual (HKI) pada Kerajinan Batik Kayu". Majalah Hukum Yustisia. Nomor 68. Surakarta: Fakultas Hukum Unversitas Sebelas Maret, 2005.

$$
\text { Peta Jalan (Road-Map) }
$$

Pengembangan Produk Unggulan Batik Dalam Kerangka Sistem Inovasi Daerah (Sida) Kota Jambi , Bappeda Kota Jambi Tahun 2015.

\section{Undang-Undang}

Kitab Undang-Undang Hukum Perdata

Undang - undang Nomor 28 Tahun 2014 tentang Hak Cipta.

Undang - undang Nomor 13 Tahun 2016 tentang Paten.

Undang - undang Nomor 20 Tahun 2016 tentang Merek dan Indikasi Geografis

Undang - undang Nomor 30 Tahun 2000 tentang Rahasia Dagang.

\section{Website}

https://psetiadharma.wordpress.com/tag/batik/.

https://jambi.antaranews.com/berita/322751/upa ya-pemerintah-menduniakan-batik-jambi https://jambikota.go.id/new/profil-industri. 